\title{
Correlations of the feeding behavior of lambs fed diets containing pearl millet silage with addition of urea
}

\section{Correlações do comportamento ingestivo de cordeiros alimentados com dietas contendo silagem de milheto com adição de ureia}

\author{
Thomaz Cyro Guimarães de Carvalho Rodrigues ${ }^{1}$; Gleidson Giordano Pinto de \\ Carvalho²; Gherman Garcia Leal de Araújo3; Edson Mauro Santos ${ }^{4}$; Poliane Meire \\ Dias de Freitas ${ }^{1}$; José Esler de Freitas Júnior ${ }^{2}$; Fabiana Lana de Araújo ${ }^{5}$; \\ Alexandre Fernandes Perazzo ${ }^{6 *}$
}

\begin{abstract}
The aim of this study was to evaluate correlations among the feeding behavior, intake, in vitro digestibility and production parameters of feedlot-finished lambs. Thirty-two male uncastrated mixed-breed lambs with an average initial live weight of $17.39 \pm 2.16 \mathrm{~kg}$ were distributed into four treatments (diets) with eight replicates (animals) each, as a function of their weight, in a completely randomized block design. Diets were composed of pearl millet silage with addition of levels of urea $(0,2,4$, and $6 \%$, DM basis), ground corn, soybean meal, and a mineral mixture. The experimental period was 62 days, consisting of 10 days of adaptation and 52 days of data collection. Positive correlations were observed $(\mathrm{P}<0.05)$ for rumination time and feeding efficiency in dry matter with the intakes of dry matter (DM), crude protein $(\mathrm{CP})$, ether extract $(\mathrm{EE})$, neutral detergent fiber $(\mathrm{NDF})$, organic matter $(\mathrm{OM})$, and non-fibrous carbohydrates (NFC). Negative correlations were detected $(\mathrm{P}<0.05)$ between rumination efficiency in NDF and the intakes of DM, EE, NDF, OM, and NFC. Correlations were negative $(\mathrm{P}<0.05)$ between the number of chews per cud and the digestibilities of DM, NDF, NFC, and TDN. The number of chews per day was negatively correlated $(\mathrm{P}<0.05)$ with the digestibility of NDF and with TDN. Rumination time had a positive correlation $(\mathrm{P}<0.05)$ with average daily gain $(\mathrm{ADG})$ and feed efficiency (FE). Feeding efficiency in DM was positively correlated $(\mathrm{P}<0.05)$ with ADG and FE, whereas rumination efficiency in NDF was negatively correlated with ADG and positively with feed conversion. The increase in feeding efficiency for dry matter generated positive effects on nutrient intake, weight gain, and feed efficiency of the lambs fed diets containing pearl millet silage with addition of urea.
\end{abstract}

Key words: Digestibility. Feeding efficiency. Weight gain. Nutrient intake.

\section{Resumo}

Objetivou-se avaliar correlações entre o comportamento ingestivo, consumo, digestibilidade in vivo e os parâmetros produtivos em cordeiros terminados em confinamento. Foram utilizados 32 cordeiros sem

\footnotetext{
1 Discentes, Programa de Pós-Graduação em Zootecnia, Universidade Federal da Bahia, UFBA, Salvador, BA, Brasil. E-mail: thomazguimaraes@yahoo.com.br; polianemeire@hotmail.com

2 Prof., UFBA, Salvador, BA, Brasil. E-mail: gleidsongiordano@yahoo.com.br; freitasjuniorje@yahoo.com.br

3 Pesquisador, Empresa Brasileira de Pesquisa Agropecuária, EMBRAPA, Centro de Pesquisa Agropecuária do Trópico Semi-Árido, Petrolina, PE, Brasil. E-mail: gherman.araujo@embrapa.br

4 Prof., Universidade Federal da Paraíba, UFPB, Areia, PB, Brasil. E-mail: edsonzootecnista@yahoo.com.br

5 Prof ${ }^{\mathrm{a}}$, Universidade Federal do Recôncavo da Bahia, UFRB, Cruz das Almas, BA, Brasil. E-mail: fabianalanadearaujo@hotmail.com

${ }^{6}$ Pesquisador Visitante, Universidade Estadual do Sudoeste da Bahia, UESB, Itapetinga, BA, Brasil. E-mail: alexandreperazzo@ hotmail.com

* Author for correspondence
} 
padrão racial definido, machos, não-castrados, com peso vivo inicial de 17,39 $\pm 2,16 \mathrm{~kg}$ distribuídos em blocos inteiramente casualizados, em função do peso, com quatro tratamentos (dietas) e oito repetições (animais). As dietas foram compostas de silagem de milheto com adição de ureia (0, 2, 4 e $6 \%$ com base na MS), grão de milho moído, farelo de soja e mistura mineral. O período experimental foi de 62 dias, sendo 10 dias de adaptação e 52 dias de coleta de dados. Observou-se correlações positivas $(\mathrm{P}<0,05)$ entre o tempo de ruminação (RUM), eficiência de alimentação da MS (EAMS) e o consumo de matéria seca (MS), proteína bruta (PB), extrato etéreo (EE), fibra em detergente neutro (FDN), matéria orgânica (MO) e carboidratos não fibrosos $(\mathrm{CNF})$. Correlações negativas $(\mathrm{P}<0,05)$ foram observadas entre a eficiência de ruminação de FDN e os consumos de MS, EE, FDN, MO e CNF. A correlação foi negativa $(\mathrm{P}<0,05)$ entre o número de mastigações por bolo (Nmbolo) e as digestibilidades da MS, FDN, CNF e NDT. O número de mastigações por dia $(\mathrm{NMM})$ se correlacionou de forma negativa $(\mathrm{P}<0,05)$ com a digestibilidade da FDN e com NDT. A variável RUM apresentou correlação positiva $(\mathrm{P}<0,05)$ com $\mathrm{o}$ ganho médio diário (GMD) e eficiência de alimentação (EA). A EAMS correlacionou-se positivamente $(\mathrm{P}<0,05)$ com GMD e EA, enquanto que, a eficiência de ruminação da FDN (ERFDN) se correlacionou negativamente com GMD e positivamente com conversão alimentar (CA). Aumento na eficiência de alimentação de matéria seca foi responsável pelos efeitos positivos no consumo de nutrientes, ganho de peso e eficiência alimentar d

Palavras-chave: Digestibilidade. Eficiência de alimentação os cordeiros alimentados com dietas contendo silagem de milheto com adição de ureia. Ganho de peso. Ingestão de nutrientes.

\section{Introduction}

Small variations in ruminant diets are already capable of modifying animal-performance parameters. Aiming to regulate the diet effects, these animals adjust their feeding behavior in an attempt to make their intake and nutrient utilization efficient (PERAZZO et al., 2017). Obtaining information pertaining to behavioral variables makes it possible to evaluate the nutritional potential of diets and make adjustments to maximize performance. The study is based upon the visual assessment of animals for a period of $24 \mathrm{~h}$ to determine the times and frequencies spent on the feeding, rumination, and idle activities (BASTOS et al., 2014).

Correia et al. (2015) stated that even the additives included in the diet of ruminants are capable of changing the intake and digestibility of nutrients and have a direct impact on their feeding behavior. Therefore, observations of correlations between behavioral and productive parameters may guide studies for possible situations in which the animal performance can be explained by their feeding behavior.

The possibility of using feeding-behavior data in the evaluation of diets may contribute to reducing the time animals are kept in the feedlot, thereby reducing expenses as well as preventing the use of invasive methods for the collection of productionrelated information (SILVA et al., 2014).

Perazzo et al. (2016) investigated the correlation between behavioral variables and those associated with intake, digestibility, and weight gain in sheep, and significant correlations were established for feed and rumination times, feed and rumination efficiencies, number of cuds ruminated, and feeding periods with the intake and digestibility of DM and nutrients, weight gain, and feed conversion.

The objective of the present study was to evaluate correlations among the feeding parameters, in vivo digestibility, and productive parameters of feedlotfinished lambs fed diets based on pearl millet silage with addition of urea.

\section{Materials and Methods}

The experiment was conducted between October and December 2013 on the caatinga biome experimental field in the metabolism unit of the Brazilian Agricultural Research Corporation (Embrapa Semi-arid), located in Petrolina - PE, Brazil. 
Thirty-two previously vaccinated and dewormed male uncastrated, mixed-breed lambs aged $4 \pm 1$ months, with an average initial body weight (BW) of $17.39 \pm 2.16 \mathrm{~kg}$, were distributed into four treatments with eight replicates, as a function of their weight, in a completely randomized design.

Lambs were identified and confined in individual, $3-\mathrm{m}^{2}$ covered metal stalls with cemented floor equipped with individual feeders and drinkers.

The experiment lasted 62 days, the first 10 of which were used for the adaptation of the animals to facilities, management, and diets, and the other 52 for collections of samples and data to evaluate the intake and digestibility of dry matter (DM) and nutrients, performance, feeding behavior, and blood metabolism.

Diets were formulated and adjusted to meet the requirements of lambs for a weight gain $200 \mathrm{~g} /$ day, following recommendations of the National Research Council (NRC, 2007). Formulation was based on the chemical composition of ingredients (Table 1), which were collected during the experimental period. The diets were composed of pearl millet silage with addition of urea levels (control, 2, 4, and 6\%, DM basis) and a concentrate based on corn, soybean, and a mineral mixture (Table 1).

Table 1. Chemical composition of diet ingredients (DM basis).

\begin{tabular}{cccc}
\hline \multirow{2}{*}{ Item } & \multicolumn{3}{c}{ Ingredient } \\
\cline { 2 - 4 } & Pearl millet silage & Ground corn & Soybean meal \\
\hline Dry matter (\% fresh matter) & 24.31 & 90.47 & 90.65 \\
Organic matter & 90.96 & 98.39 & 94.58 \\
Mineral matter & 9.04 & 1.61 & 5.42 \\
Crude protein (CP) & 10.86 & 8.76 & 54.17 \\
Ether extract & 2.10 & 3.50 & 0.89 \\
NDIP $^{1}$ (\% CP) & 47.89 & 35.28 & 32.63 \\
ADIP $^{2}$ (\% CP) & 14.61 & 11.87 & 1.39 \\
Neutral detergent fiber ap & 63.62 & 16.84 & 19 \\
Acid detergent fiber ap & 34.77 & 5.16 & 9.47 \\
Lignin & 4.16 & 3.86 & 1.31 \\
Cellulose & 30.61 & 1.30 & 8.16 \\
Hemicellulose & 32.29 & 10.93 & 4.47 \\
Non-fibrous carbohydrates & 14.38 & 69.29 & 20.52 \\
\hline
\end{tabular}

${ }^{1}$ Neutral detergent insoluble protein, ${ }^{2}$ Acid detergent insoluble protein. ${ }^{3}$ Corrected for ash and protein.

The feed was supplied ad libitum twice daily, at $08 \mathrm{~h} 00$ and $16 \mathrm{~h} 00$, estimating orts at $10 \%$ of the total supplied, on the basis of the intake of the previous day. Water was available ad libitum. During the experiment, weekly samples of ingredients and orts were collected for analyses of chemical and centesimal composition (Table 2).
The pearl millet (Pennisetum glaucum) variety used was cultivar ADR 500, seeded on the Bebedouro Experimental Field at the Plant Production Unit of Embrapa Semiarid. The forage was harvested manually, at the chronological age of 72 days after planting, when the grains had a milky/ doughy consistency. After harvesting, the pearl 
millet forage was immediately moved to a covered shed, where it was ensiled. Composite samples of millet were collected before the ensiling process, for the characterization of the chemical composition.

The pearl millet silage was chopped through a stationary forage chopper regulated to generate particles of approximately $2 \mathrm{~cm}$. Samples of the pearl millet were collected prior to ensiling to determine its chemical composition (as a \% of $\mathrm{DM}$ ), and the following results were obtained:
$24.31 \%$ dry matter, $90.96 \%$ organic matter, $9.04 \%$ mineral matter, $10.86 \%$ crude protein, $2.1 \%$ ether extract, $63.62 \%$ neutral detergent fiber, $34.77 \%$ acid detergent fiber, and $4.16 \%$ lignin. Later, urea was added to the forage laid on a canvas sheet on the shed's floor and the chopped material was homogenized at the following ratios: for every 130 $\mathrm{kg}$ of fresh forage, $0.78,1.56$, and $2.34 \mathrm{~kg}$ of urea corresponding to the urea levels of 2,4 , and $6 \%$, respectively (one a forage DM basis)

Table 2. Centesimal composition of ingredients and chemical composition of diets.

\begin{tabular}{ccccc}
\hline Ingredient (\% DM) & \multicolumn{4}{c}{ Urea in the silage (\%) } \\
\cline { 2 - 4 } & 0 & 2 & 4 & 6 \\
\hline Ground corn & 19.08 & 18.74 & 21.28 & 18.28 \\
Soybean meal & 3.84 & 3.56 & 1.82 & 4.05 \\
Mineral supplement ${ }^{\mathrm{a}}$ & 1.73 & 1.70 & 1.90 & 1.67 \\
Urea & 0.35 & 0.00 & 0.00 & 0.00 \\
Pearl millet silage & 75.00 & 76.00 & 75.00 & 76.00 \\
Total & 100.00 & 100.00 & 100.00 & 100.00 \\
\hline & Chemical composition of the diets & \\
\hline Dry matter (\% fresh matter) & 38.25 & 37.55 & 40.14 & 37.10 \\
Organic matter & 91.43 & 90.88 & 90.33 & 90.66 \\
Mineral matter & 8.21 & 9.11 & 9.65 & 9.35 \\
Crude protein & 15.22 & 15.81 & 14.01 & 16.55 \\
Ether extract & 2.51 & 2.60 & 2.57 & 2.84 \\
PIDN ${ }^{1} \%$ CP) & 17.63 & 20.10 & 25.61 & 24.56 \\
ADIP ${ }^{2} \%$ CP) & 7.84 & 8.78 & 10.98 & 12.79 \\
Neutral detergent fiber ap ${ }^{3}$ & 44.51 & 48.32 & 49.86 & 52.85 \\
Acid detergent fiber ap ${ }^{3}$ & 28.00 & 28.78 & 31.64 & 34.69 \\
Lignin $_{\text {Cellulose }}$ & 3.23 & 4.15 & 4.97 & 6.25 \\
Hemicellulose $_{\text {Non-fibrous carbohydrates }}$ & 24.77 & 24.63 & 26.67 & 28.44 \\
Total digestible nutrients & & 18.83 & 18.43 & 18.11 \\
\hline
\end{tabular}

aProvides per 1,000 mg minimum value: calcium - $141.48 \mathrm{~g}$; phosphorus - $43 \mathrm{~g}$; sodium - 214,50 g; sulfur - $16 \mathrm{~g}$; copper - 700 mg; cobalt - $50 \mathrm{mg}$; iron - 2,700 mg; iodine - $50 \mathrm{mg}$; manganese - 1,500 mg; selenium - $25 \mathrm{mg}$; zinc - 1,800 mg; chloride - 330 g; fluorine $-431 \mathrm{mg}$.

${ }^{1} \mathrm{NDIP}=$ neutral detergent indigestible protein, ${ }^{2} \mathrm{ADIP}=$ acid detergent indigestible protein. ${ }^{3} \mathrm{ap}=$ corrected for ash and protein. ${ }^{4}$ Total digestible nutrients estimated by the equations of Detmann and Valadares Filho (2010). 
In the ensiling processes, 25 silos were made from 200-L plastic drums $(96 \mathrm{~cm}$ height $\times 60 \mathrm{~cm}$ length $\times 60 \mathrm{~cm}$ width), using $130 \mathrm{~kg}$ of fresh matter per silo. The forage was compacted by trampling. Subsequently, after being filled, silos were sealed with plastic lids and aluminum clamps and stored in a covered shed.

The experiment was divided into two 26-day periods. During these periods, samples of the feed supplied (roughage and concentrate), orts, and feces were collected, placed in plastic bags, identified, and stored in a freezer at $-20{ }^{\circ} \mathrm{C}$. For the analyses, these samples were thawed and pre-dried in a forced-air oven at $55^{\circ} \mathrm{C}$ for $72 \mathrm{~h}$ (SILVA; QUEIROZ, 2002), ground through Wiley mill with 1-mm sieves, and stored in properly identified plastic jars with lid.

The period for the estimation of the digestibility of DM and nutrients was the 30th to the 37th day in the feedlot. These variables were estimated by the total feces collection method, using collection bags. After adaptation to the collection bags, feces were collected from the animals in five subsequent days, twice daily, at $08 \mathrm{~h} 00$ and $15 \mathrm{~h} 00$. Approximately $10 \%$ of the total feces contained in each bag were harvested, placed in individual plastic bags, stored, and frozen at $-20{ }^{\circ} \mathrm{C}$.

Analyses for the chemical composition of samples of feedstuffs, feeds, and orts were performed at the Laboratory of Animal Nutrition of the State University of Southwest Bahia (UESB).

We determined the concentrations of $\mathrm{DM}$ as a percentage of the fresh matter; and, organic matter $(\mathrm{OM})$, ether extract (EE), mineral matter (MM), crude protein $(\mathrm{CP})$, and lignin in $72 \%$ sulfuric acid as a percentage of DM, according to the methodologies described by AOAC (1990). Neutral detergent fiber (NDF) and acid detergent fiber (ADF) were determined also as a percentage of DM, but following Mertens (2002), and corrected for the MM and $\mathrm{CP}$ contents. The concentrations of neutral (NDIP) and acid (ADIP) detergent insoluble protein contents were determined as a percentage of
CP, following Licitra et al. (1996).

Total digestible nutrients (TDN) contents were estimated by the formula proposed by Weiss (1999), as follows: $\mathrm{TDN}=\mathrm{DCP}+(2.25 \times \mathrm{DEE})+\mathrm{DNFC}$ + DNDF, where DCP, DEE, DNFC, and DNDF are the digestible fractions of crude protein, ether extract, non-fibrous carbohydrates, and neutral detergent fiber, respectively. The concentrations of non-fibrous carbohydrates corrected for ash and protein (NFCap) were calculated as proposed by Detmann and Valadares Filho (2010):

$\mathrm{NFC}=100-[(\% \mathrm{CP}-\% \mathrm{CPurea}+\%$ urea $)+\% \mathrm{FDNcp}+\% \mathrm{EE}+\% \mathrm{MM}]$

The intakes of DM and nutrients were calculated as the difference between the feed supplied and the orts. Feed conversion (FC) was estimated as the average DM intake of the lambs ( $\mathrm{kg}$ animal day $^{-1}$ ) divided by their average daily gain (ADG, $\mathrm{kg}$ animal $\mathrm{day}^{-1}$ ), which was calculated as the difference between final and initial body weight of the animals divided by the number of days in the experimental period (52 days), expressed as $\mathrm{kg}$ day $^{-1}$. The digestibility coefficients of DM, CP, EE, NDFap, and NFC were calculated by the equation described by Schneider and Flatt (1975):

$$
D C=\frac{(\mathrm{kg} \text { of the ingested fraction }-\mathrm{kg} \text { of the excreted fraction })}{(\mathrm{kg} \text { of the ingested fraction })} \times 100
$$

For the evaluation of feeding behavior, the animals were visually observed for $24 \mathrm{~h}$ on the 18th and 48th days of the experimental period. Observations took place at 10 -min intervals, to quantify the feeding, rumination, and idle times (CARVALHO et al., 2007). During the night-time observations, the environment was kept illuminated artificially.

To evaluate the chewing activities, three observations were made per animal on the 18th and 48th days, divided into three periods of the day (morning, afternoon, and night), on which occasions the number and duration of chews per ruminal cud were recorded with digital stopwatches used by four trained observers that were positioned so as not to 
interfere with the animals' behavior.

To estimate the feeding and rumination times ( $\mathrm{min} / \mathrm{kg} \mathrm{DM}$ and min $\mathrm{kg} \mathrm{NDF}^{-1}$ ), feeding efficiency (g DM and NDF $\mathrm{h}^{-1}$ ), and average intakes of DM and NDF per feeding period, we used the voluntary intakes of DM and NDF observed on the 18th and 48th days, corresponding to the intakes of the days the behavioral data were collected. Behavioral variables were obtained by following the method described by Burgüer et al. (2000).

The number of cuds ruminated daily was calculated by dividing the total rumination time (min) by the average time spent on the rumination of one cud. The concentrations of DM and NDF in each ruminated cud $(\mathrm{g})$ was obtained by dividing the amounts of DM and NDF consumed $\left(\mathrm{g} \mathrm{day}^{-1}\right)$ in $24 \mathrm{~h}$ by the number of cuds ruminated per day.

Feeding efficiency in DM and NDF was expressed by the formulae below:

$$
F E D M=\frac{D M I}{F T} \text { and } F E N D F=\frac{N D F I}{F T},
$$

where FEDM (g DM intake $\mathrm{h}^{-1}$ ) and FENDF (g NDF intake $\mathrm{h}^{-1}$ ) = feeding efficiency; DMI and NDFI = daily intakes of DM and NDF, respectively; and FT $=$ time spent feeding per day.

Rumination efficiency in DM and NDF was obtained by the following formulae:

$$
R E D M=\frac{D M I}{R T} \text { and } R E N D F=\frac{N D F I}{R T},
$$

where REDM (g DM ruminated $\mathrm{h}^{-1}$ ); RENDF (g NDF ruminated $\mathrm{h}^{-1}$ ) = rumination efficiency; DMI and NDFI = daily intakes of DM and NDF, respectively; and $\mathrm{RT}=$ time spent ruminating per day.

The total chewing time was obtained as shown below:

$$
T C h T=F T+R T,
$$

where $\operatorname{TChT}(\min /$ day $)=$ total chewing time.

The number of feeding, rumination, and idle periods were obtained by observing the sequential number of activities in the records spreadsheet and dividing the total duration of each activity by the respective number of periods (BURGÜER et al., 2000).

Samples of roughage, concentrate, and orts from each animal, from the days of feeding behavior evaluation, were stored at $-20{ }^{\circ} \mathrm{C}$ in identified plastic bags for a subsequent analysis of intake and feeding efficiencies.

The correlations among intake, digestibility, animal performance, and behavior were interpreted by Pearson's linear correlation analyses and processed using the SAEG package (Systems for Statistical and Genetic Analyses) (SAEG, 2007), considering $5 \%$ as the critical level of probability.

\section{Results and Discussion}

Idle time (IT), rumination efficiency in grams of NDF ( $\left(\mathrm{RE}_{\mathrm{NDF}}\right)$, grams of NDF per cud (GNDF), and idle time per period (ITP) had a negative correlation $(\mathrm{P}<0.05)$ with the intake variables (Table 3$)$, except for the intake of crude protein, whose effect was not significant $(\mathrm{P}>0.05)$. For rumination time (RT), feeding efficiency in dry matter $\left(\mathrm{FE}_{\mathrm{DM}}\right)$, number of ruminated cuds (NRC), average number of chews per day (NChD), total chewing time (TChT), time per rumination period (TRP), and number of idle periods (NIP), positive correlations $(\mathrm{P}<0.05)$ were observed with the intake variables. These results are associated with the higher NDF intake that directly influences the time and periods spent feeding. These effects are explained by Carvalho et al. (2006), who evaluated levels of fiber in goat diets and found an increase in the time spent on the rumination of feeds with a high fiber content, which improved the utilization of their components by the reduction of the particles, contributing to the rumen degradation. In the present study, the positive correlation between nutrient intake and rumination time benefited feeding efficiency in dry matter, indicating that the fiber levels in the diet did not negatively influence feed intake. 
There were correlations $(\mathrm{P}<0.05)$ between the rumination times and the intakes of DM $(r=0.547)$, $\mathrm{CP}(\mathrm{r}=0.374), \mathrm{EE}(\mathrm{r}=0.578), \mathrm{NDF}(\mathrm{r}=0.597), \mathrm{OM}$ $(r=0.546)$, and NFC $(r=0.524)$. The rumination time depends directly on the intake and composition of the ingested material, with larger fibrous contents meaning a longer time on this activity, as explained previously.

The intakes of DM $(r=-0.439)$, EE $(r=-0.543)$, $\mathrm{NDF}(\mathrm{r}=-0.492)$, OM $(\mathrm{r}=-0.435)$, and NFC $(\mathrm{r}$ $=-0.428)$ had a negative correlation $(\mathrm{P}<0.05)$ with idle time. These negative correlations confirm the previous findings showing that an increase in intake leads to longer feeding and rumination times and consequently less idle time.

Positive correlations were detected $(\mathrm{P}<0.05)$ between $\mathrm{FE}_{\mathrm{DM}}$ and the intakes of the following components: DM $(r=0.616), \mathrm{CP}(\mathrm{r}=0.544), \mathrm{EE}$ $(r=0.524), \mathrm{NDF}(r=0.643), \mathrm{OM}(r=0.623)$ and NFC $(r=0.573)$. An increase in intake leads to higher rumination efficiency in dry matter $\left(\mathrm{RE}_{\mathrm{DM}}\right)$; however, the magnitudes of differences in intakes must be expressive for alterations to be observed in the feeding, rumination, and idle activities.

Negative correlations were observed $(\mathrm{P}<0.05)$ between $\mathrm{RE}_{\mathrm{NDF}}$ and the intakes of $\mathrm{DM}, \mathrm{EE}, \mathrm{NDF}$, $\mathrm{OM}$, and NFC. This result is a consequence of the lower need for rumination in high-concentrate diets (BURGÜER et al., 2000), as was the present case, which reduced the optimization of $\mathrm{RE}_{\mathrm{NDF}}$ in relation to the intake of nutrients. According to Cardoso et al. (2006), the rumination efficiency of the NDF fraction increases as the dietary fiber level is increased.

The number of ruminated cuds (NRC) and the average number of chews per day (NChD) had a positive correlation with all intake variables $(\mathrm{P}<0.05)$. A positive correlation $(\mathrm{P}<0.05)$ was observed between total chewing time (TChT) and the intakes, except that of crude protein. However, the correlation between grams of NDF per cud (GNDF) and the intakes was negative, except for the intake of crude protein, for which there was no correlation. Burgüer et al. (2000) observed that there is a correlation between the chewing time and intake and that an increase in the dietary fiber content extends the chewing time. The chewing variables are related to the feeding and rumination times; therefore, they followed the same positivecorrelation trend in regard to intake, indicating that the increase in number of chews was necessary to elevate feed intake.

The chewing activities are important mechanisms in the particle-size reduction process, accounting for over $80 \%$ of the total breaking of particles (MCLEOD; MINSON, 1988). Carvalho and Pires (2008) explained that the chewing process is very important not only for reducing the particle size, but also for producing fissures that serve as a gateway to the rumen microorganisms. 
Table 3. Linear correlations between feeding-behavior parameters and intakes of dry matter and nutrients by lambs fed diets based on pearl millet silage with addition of urea.

\begin{tabular}{|c|c|c|c|c|c|c|c|c|c|c|c|c|}
\hline \multirow[t]{2}{*}{ Variable } & \multicolumn{2}{|c|}{ DMI } & \multicolumn{2}{|c|}{ CPI } & \multicolumn{2}{|c|}{ EEI } & \multicolumn{2}{|c|}{ NDFI } & \multicolumn{2}{|c|}{ OMI } & \multicolumn{2}{|c|}{ NFCI } \\
\hline & $\mathrm{R}$ & $\mathrm{P}$ & $\mathrm{R}$ & $\mathrm{P}$ & $\mathrm{R}$ & $\mathrm{P}$ & $\mathrm{R}$ & $\mathrm{P}$ & $\mathrm{r}$ & $\mathrm{P}$ & $\mathrm{r}$ & $\mathrm{P}$ \\
\hline RT (min day $\left.{ }^{-1}\right)$ & 0.547 & 0.0009 & 0.374 & 0.021 & 0.578 & 0.0004 & 0.597 & 0.0003 & 0.546 & 0.0009 & 0.524 & 0.0015 \\
\hline IT ( min day ${ }^{-1}$ ) & -0.439 & 0.0076 & $* * *$ & $* * *$ & -0.543 & 0.001 & -0.492 & 0.0029 & -0.435 & 0.0081 & -0.428 & 0.0092 \\
\hline $\mathrm{FE}_{\mathrm{DM}}\left(\mathrm{g} \mathrm{h}^{-1}\right)$ & 0.616 & 0.0001 & 0.544 & & 0.524 & 0.0015 & 0.643 & 0.0001 & 0.623 & 0.0001 & 0.573 & 0.0005 \\
\hline $\mathrm{RE}_{\mathrm{NDF}}\left(\mathrm{g} \mathrm{h}^{-1}\right)$ & -0.392 & 0.0161 & $* * *$ & $* * *$ & -0.427 & 0.0093 & -0.393 & 0.0158 & -0.39 & 0.0167 & -0.389 & 0.0169 \\
\hline NRC $\left(\right.$ n day $\left.^{-1}\right)$ & 0.529 & 0.0013 & 0.362 & & 0.521 & 0.0016 & 0.592 & 0.0003 & 0.53 & 0.0013 & 0.501 & 0.0024 \\
\hline $\mathrm{NChD}\left(\mathrm{n} \mathrm{day}^{-1}\right)$ & 0.545 & 0.0009 & 0.429 & & 0.549 & 0.0008 & 0.564 & 0.0006 & 0.545 & 0.0009 & 0.524 & 0.0015 \\
\hline TChT (h day $\left.{ }^{-1}\right)$ & 0.439 & 0.0076 & $* * *$ & $* * *$ & 0.543 & 0.001 & 0.492 & 0.0029 & 0.435 & 0.0081 & 0.428 & 0.0092 \\
\hline GNDF $\left(\mathrm{g} \mathrm{cud}^{-1}\right)$ & -0.332 & 0.0366 & $* * *$ & $* * *$ & -0.353 & 0.0278 & -0.344 & 0.0313 & -0.33 & 0.0375 & -0.329 & 0.0381 \\
\hline RPD $\left(\right.$ n day $\left.^{-1}\right)$ & 0.595 & 0.0003 & 0.412 & & 0.608 & 0.0002 & 0.651 & $<0.01$ & 0.594 & 0.0003 & 0.57 & 0.0005 \\
\hline TPR $\left(\right.$ min period $\left.^{-1}\right)$ & 0.419 & 0.0106 & $* * *$ & $* * *$ & 0.448 & 0.0066 & 0.451 & 0.0062 & 0.419 & 0.0106 & 0.402 & 0.0139 \\
\hline $\operatorname{NIP}\left(\mathrm{n}_{\text {day }}{ }^{-1}\right)$ & 0.37 & 0.0221 & $* * *$ & $* * *$ & 0.52 & 0.0016 & 0.399 & 0.0144 & 0.363 & 0.0245 & 0.369 & 0.0223 \\
\hline TIP $\left(\min\right.$ period $\left.{ }^{-1}\right)$ & -0.468 & 0.0045 & $* * *$ & $* * *$ & -0.599 & 0.0002 & -0.518 & 0.0017 & -0.462 & 0.0051 & -0.458 & 0.0055 \\
\hline
\end{tabular}

$\mathrm{DMI}=$ dry matter intake, $\mathrm{CPI}=$ crude protein intake, $\mathrm{EEI}=$ ether extract intake, $\mathrm{NDFI}=$ neutral detergent fiber intake, $\mathrm{OMI}=$ organic matter intake, $\mathrm{NFCI}=$ non-fibrous carbohydrates intake, $\mathrm{RT}=$ rumination time, $\mathrm{IT}=$ idle time, $\mathrm{FE}_{\mathrm{DM}}=\mathrm{feeding}_{\mathrm{efficiency}}$ in $\mathrm{DM}, \mathrm{RE}_{\mathrm{NDF}}=$ rumination efficiency in $\mathrm{NDF}, \mathrm{NRC}=$ number of ruminated cuds, $\mathrm{NChD}=$ average number of chews per day, TChT $=$ total chewing time, GNDF $=$ grams of NDF, RPD = number of rumination periods per day, $\mathrm{TPR}=$ time per rumination period, $\mathrm{NIP}=$ number of idle periods, TIP $=$ time per idle period.

There was a positive correlation $(\mathrm{P}<0.05)$ of the number of rumination periods per day (RPD) and the time per rumination period (TRP) with the intake variables, suggesting that an increase in intake also increases the total time (hours) spent on rumination and the time spent in each period. As previously mentioned, the elevation of rumination activities is a result of an increase in intake rates, which explains the positive correlations obtained here. This explains the positive feeding efficiency in $\mathrm{DM}$, since there was adequate rumination that allowed higher nutrient intakes in relation to the chewing time; this fact is associated with the rapid rumen degradation promoted by rumination.

The time per idle period (TIP) was negatively correlated with the intake variables $(\mathrm{P}<0.05)$. The behavioral activities are mutually exclusionary, and, for this reason, the longer feeding and rumination times related to intake result in less time spent idle, leading to a negative correlation between time per idle period and nutrient intake.

There was a negative correlation $(\mathrm{P}<0.05)$ between the number of chews per cud $(\mathrm{NChC})$ and the digestibility variables presented here (Table 4). For the average chewing time per cud (ChTC), a negative correlation also occurred with these variables $(\mathrm{P}<0.05)$, except for the digestibility of non-fibrous carbohydrates (DNFC). Feeds with higher digestibility tend to require a smaller number of chews per cud. 
Table 4. Linear correlation between the feeding-behavior parameters and digestibility of nutrients and total digestible nutrients in lambs fed diets based on pearl millet silage with addition of urea.

\begin{tabular}{|c|c|c|c|c|c|c|c|c|}
\hline \multirow[t]{2}{*}{ Variable } & \multicolumn{2}{|c|}{ DDM } & \multicolumn{2}{|c|}{ DNDF } & \multicolumn{2}{|c|}{ DNFC } & \multicolumn{2}{|c|}{ TDN } \\
\hline & $\mathrm{R}$ & $\mathrm{P}$ & $\mathrm{R}$ & $\mathrm{P}$ & $\mathrm{r}$ & $\mathrm{P}$ & $\mathrm{r}$ & $\mathrm{P}$ \\
\hline $\mathrm{NChC}\left(\mathrm{n} \mathrm{cud}^{-1}\right)$ & -0.3480 & 0.0297 & -0.3950 & 0.0154 & -0.3167 & 0.0441 & -0.3831 & 0.0183 \\
\hline $\operatorname{ChTC}\left(\operatorname{min~cud}^{-1}\right)$ & -0.3669 & 0.0231 & -0.3712 & 0.0217 & $* * *$ & $* * *$ & -0.3727 & 0.0213 \\
\hline $\operatorname{NChD}\left(\right.$ day $\left.^{-1}\right)$ & $* * *$ & $* * *$ & -0.3131 & 0.0460 & $* * *$ & $* * *$ & -0.3069 & 0.0495 \\
\hline $\operatorname{NRP}\left(\right.$ n day $\left.{ }^{-1}\right)$ & $* * *$ & $* * *$ & -0.3538 & 0.0275 & $* * *$ & $* * *$ & -0.3430 & 0.0318 \\
\hline TPM (min meal $\left.{ }^{-1}\right)$ & $* * *$ & $* * *$ & -0.4072 & 0.0128 & $* * *$ & $* * *$ & -0.3498 & 0.029 \\
\hline
\end{tabular}

$\mathrm{DDM}=$ digestibility of dry matter, DNDF = digestibility of neutral detergent fiber, DNFC = digestibility of non-fibrous carbohydrates, $\mathrm{TDN}=$ total digestible nutrients, $\mathrm{NChC}=$ number of chews per cud, $\mathrm{ChTC}=$ average chewing time per cud, $\mathrm{NChD}$ $=$ average number of chews per day, $\mathrm{NRP}=$ number of rumination periods, $\mathrm{TPM}=$ time per meal.

The time spent chewing reduces as the digestibility of the consumed material is increased. According to Dias et al. (2014), the rumination process benefits the utilization of the diet components through the rumen buffering as well as the reduction of the feed particle size. In this way, digestibility is promoted when rumination time is extended.

The average number of chews per day (NChD) and the number of rumination periods (NRP) had a negative correlation $(\mathrm{P}<0.05)$ with $\mathrm{DNDF}$ and TDN. Perazzo et al. (2016) evaluated correlations of the feeding behavior of lambs and did not observe a relationship between the chewing activities and digestibility. Those authors explained that the lack of influence of rumination on digestibility was responsible for these results. In the present study, a negative correlation was observed $(\mathrm{P}<0.05)$ between time per meal (TPM) and DNDF and TDN.

As can be seen in Table 5, the rumination time (RT) was positively correlated $(\mathrm{P}<0.05)$ with ADG and FE. However, this variable had a negative correlation with FC.

Table 5. Linear correlations between the feeding-behavior and productive-performance parameters of lambs fed diets based on pearl millet silage with addition of urea.

\begin{tabular}{|c|c|c|c|c|c|c|}
\hline \multirow{2}{*}{ Variable } & \multicolumn{2}{|c|}{$\mathrm{ADG}$} & \multicolumn{2}{|c|}{$\mathrm{FC}$} & \multicolumn{2}{|c|}{$\mathrm{FE}$} \\
\hline & $\mathrm{R}$ & $\mathrm{P}$ & $\mathrm{r}$ & $\mathrm{P}$ & $\mathrm{R}$ & $\mathrm{P}$ \\
\hline RT $\left(\min\right.$ day $\left.^{-1}\right)$ & 0.7266 & $<0.001$ & -0.563 & 0.0006 & 0.5829 & 0.0004 \\
\hline IT $\left(\min\right.$ day $\left.^{-1}\right)$ & -0.584 & 0.0004 & 0.3996 & 0.0143 & -0.4705 & 0.0043 \\
\hline $\mathrm{NChC}\left(\mathrm{n} \mathrm{cud}^{-1}\right)$ & 0.4264 & 0.0094 & $* * *$ & $* * *$ & 0.4189 & 0.0106 \\
\hline $\mathrm{TMM}\left(\mathrm{min} \mathrm{cud}^{-1}\right)$ & 0.391 & 0.0163 & $* * *$ & $* * *$ & 0.4471 & 0.0066 \\
\hline $\mathrm{FE}_{\mathrm{DM}}\left(\mathrm{g} \mathrm{h}^{-1}\right)$ & 0.6902 & $<0.001$ & -0.4873 & 0.0032 & 0.4979 & 0.0026 \\
\hline $\mathrm{RE}_{\mathrm{NDF}}\left(\mathrm{g} \mathrm{h}^{-1}\right)$ & -0.4229 & 0.001 & 0.3494 & 0.0292 & -0.3825 & 0.0185 \\
\hline $\mathrm{NRC}\left(\mathrm{n}\right.$ day $\left.^{-1}\right)$ & 0.6127 & 0.0002 & -0.4903 & 0.003 & 0.447 & 0.0066 \\
\hline $\operatorname{NChD}\left(\right.$ nday $\left.^{-1}\right)$ & 0.7338 & $<0.001$ & 0.5772 & 0.0004 & 0.5815 & 0.0004 \\
\hline TCT $\left(\mathrm{h}\right.$ day $\left.^{-1}\right)$ & 0.584 & 0.0004 & -0.3996 & 0.0143 & 0.4705 & 0.0043 \\
\hline GNDF $\left(\mathrm{g} \mathrm{cud}^{-1}\right)$ & -0.3176 & 0.0436 & 0.3178 & 0.0435 & $* * *$ & $* * *$ \\
\hline
\end{tabular}

Continue... 
Continuation...

\begin{tabular}{ccccccc}
$\mathrm{NRP}\left(\mathrm{n}\right.$ day $\left.^{-1}\right)$ & 0.6705 & $<0.001$ & -0.4812 & 0.0035 & 0.5793 & 0.0004 \\
$\mathrm{TRP}\left(\right.$ min period $\left.^{-1}\right)$ & 0.6334 & 0.0001 & -0.5289 & 0.0013 & 0.5055 & 0.0022 \\
$\mathrm{NIP}\left(\mathrm{n}\right.$ day $\left.^{-1}\right)$ & 0.4255 & 0.0095 & $* * *$ & $* * *$ & 0.38 & 0.0192 \\
TIP $\left(\right.$ min period $\left.^{-1}\right)$ & -0.5959 & 0.0003 & 0.3755 & 0.0204 & -0.5149 & 0.0018 \\
\hline
\end{tabular}

$\mathrm{ADG}=$ average daily gain in grams, $\mathrm{FC}=$ feed conversion, $\mathrm{FE}=$ feed efficiency, $\mathrm{RT}=$ rumination time, $\mathrm{IT}=\mathrm{idle}$ time, $\mathrm{NChC}=$ number of chews per cud, $\mathrm{ChTC}=$ average chewing time per cud, $\mathrm{FE}_{\mathrm{DM}}=$ feeding efficiency in $\mathrm{DM}, \mathrm{RE}_{\mathrm{NDF}}=$ rumination efficiency in NDF, NRC = number of ruminated cuds, $\mathrm{NCh}=$ average number of chews per day, TChT $=$ total chewing time, GNDF $=$ grams of NDF, NRP = number of rumination periods, TRP $=$ time per rumination period, NIP $=$ number of idle periods, TIP $=$ time per idle period.

Idle time (IT) were positively correlated with ADG and FC and negatively with FE. A longer time spent idle stems from less time on the feeding and/ or rumination activities. This can influence intake and consequently the average weight gain. This correlation was also observed by Perazzo et al. (2016), who evaluated the productive performance of lambs fed diets containing buffelgrass hay ammoniated with urea.

The correlation $(\mathrm{P}<0.05)$ of number of chews per cud $(\mathrm{NChC})$ and average chewing time per cud (ChTC) with ADG and FE was positive. This significant correlation indicates that the animals were able to ingest larger amounts of nutrients because of the increased chewing activities (Table $3)$, resulting in better production performance.

There was a correlation $(\mathrm{P}<0.05)$ between feeding efficiency in dry matter $\left(\mathrm{FE}_{\mathrm{DM}}\right)$ and the production-performance variables such as $\mathrm{ADG}$ and FE. However, the correlation between $\mathrm{FE}_{\mathrm{DM}}$ and $\mathrm{FC}$ was negative. The principle for animal production lies upon the intake of nutrients according to the nutritional requirements of the individuals, based on the DM intake. Thus, it is assumed that satisfactory dietary conditions allowed for an improvement in performance, since the increase in feeding efficiency in DM is directly related to intake (DIAS et al., 2014).

Rumination efficiency in NDF $\left(\mathrm{RE}_{\mathrm{NDF}}\right)$ was negatively correlated $(\mathrm{P}<0.05)$ with $\mathrm{ADG}$ and $\mathrm{FE}$ and positively with FC. Perazzo et al. (2017) stated that the rumination efficiency led to increased intake and better utilization of the feed by feedlot lambs. However, the present study indicates that rumination was not responsible for the utilization efficiency of the feedstuffs, which is explained by the high nutritional value of the diet (WELCH, 1982).

The correlation $(\mathrm{P}<0.05)$ of number of ruminated cuds (NRC) and ADG with FE was positive, but negative with FC. The more an animal ruminates, the better the feed-particle reduction process and consequently the better its utilization (DIAS et al., 2014). Total chewing time (TChT) had a positive correlation $(\mathrm{P}<0.05)$ with $\mathrm{ADG}$ and $\mathrm{FE}$ and a negative correlation with FC. A longer chewing time may be related to higher feed intake and consequently higher nutrient intake, which benefits the daily weight gain and feeding efficiency.

Grams of NDF per cud (GNDF) had a negative correlation $(\mathrm{P}<0.05)$ with $\mathrm{ADG}$ and a positive correlation with FC. According to Dias et al. (2014), this is explained by the passage rate of the roughage, in which case the limiting factor is the filling effect caused by NDF, which limits intake, thereby reducing $\mathrm{ADG}$.

The number of rumination periods (NRP) and the time per rumination period (TRP) had a positive correlation with $\mathrm{ADG}$ and $\mathrm{FE}$ and a negative correlation with FC. These findings confirm that 
rumination was in synchrony with the feeding activity, which was provided by the diet, leading to a high feed efficiency. This explains that rumination positively favored the productive-performance variables.

The time per idle period (TIP) had a negative correlation $(\mathrm{P}<0.05)$ with $\mathrm{ADG}$ and $\mathrm{FE}$ and a positive correlation with FC. A longer time per idle period results in more time for this activity and less time for the others such as feeding, which results in a lower intake of nutrients and consequently lower daily gain and feed efficiency.

Our results indicate that the diet provided balance between the feeding and rumination activities, which optimized the utilization of the feedstuffs through the feeding efficiency in dry matter. The positive correlation of nutrient intake, weight gain, and feed efficiency with rumination efficiency in dry matter explains the performance of feedlot-finished lambs fed diets based on pearl millet silage with addition of urea.

\section{Conclusions}

The increase in feed efficiency for dry matter generated positive effects on the nutrient intake, weight gain, and feed efficiency of lambs fed diets containing pearl millet silage with addition of urea.

\section{References}

ASSOCIATION OF OFFICIAL ANALYTICAL CHEMISTS - AOAC. Official methods of analysis. $15^{\text {th }}$ ed. Arlington: AOAC International, 1990.

BASTOS, M. P. V.; CARVALHO, G. G. P.; PIRES, A. J. V.; SILVA, R. R.; EUSTÁQUIO FILHO, A.; SANTOS, E. J.; CHAGAS, D. M. T.; BARROSO, D. S.; ABREU FILHO, G. Ingestive behavior and nitrogen balance of confined Santa Ines lambs fed diets containing soybean hulle. Journal of Animal Science, Champaign, v. 27, n. 1, p. 24-29, 2014.

BURGÜER, P. J.; PEREIRA, J. C.; QUEIROZ, A. C.; SILVA, J. F. C.; VALADARES FILHO, S. C.; CECON, P. R.; CASALI, A. D. P. Comportamento ingestivo em bezerros holandeses alimentados com dietas contendo diferentes níveis de concentrado. Revista Brasileira de Zootecnia, Viçosa, MG, v. 29, n. 1, p. 236-242, 2000.

CARDOSO, A. R.; CARVAlHO, S.; GALVANI, D. B.; PIRES, C. C.; GASPERIN, B. G. Comportamento ingestivo de cordeiros alimentados com dietas contendo diferentes níveis de fibra em detergente neutro. Ciência Rural, Santa Maria, v. 36, n. 2, p. 604-609, 2006.

CARVALHO, G. G. P.; PIRES, A. J. V. Organização dos tecidos de plantas forrageiras e suas implicações para os ruminantes. Archivos de Zootecnia, Córdoba, v. 57, n. 1, p. 13-28, 2008.

CARVALHO, G. G. P.; PIRES, A. J. V.; SILVA, R. R.; CARVALHO, B. M. A. D. U.; SILVA, H. G. D. O.; CARVALHO, L. M. D. U. Aspectos metodológicos do comportamento ingestivo de ovinos alimentados com capim-elefante amonizado e subprodutos agroindustriais. Revista Brasileira de Zootecnia, Viçosa, MG, v. 36, n. 1, p. 1105-1112, 2007

CARVALHO, S.; RODRIGUES, M. T.; BRANCO, R. H.; RODRIGUES, C. A. F. Comportamento ingestivo de cabras Alpinas em lactação alimentadas com dietas contendo diferentes níveis de fibra em detergente neutro proveniente da forragem. Revista Brasileira de Zootecnia, Viçosa, MG, v. 35, n. 2, p. 562-568, 2006.

CORREIA, B. R.; CARVALHO, G. G. P.; OLIVEIRA, R. L.; PIRES, A. J. V. A.; RIBEIRO, O. L.; SILVA, R. R.; LEÃO, A. G.; RODRIGUES, C. S. Feeding behavior of feedlot-finished young bulls fed diets containing peanut cake. Tropical Animal Health and Production, Edinburgh, v. 47, n. 6, p. 1075-1081, 2015.

DETMANN, E.; VALADARES FILHO, S. C. On the estimation of non-fibrous carbohydrates in feeds and diets. Arquivo Brasileiro de Medicina Veterinária e Zootecnia, Belo Horizonte, v. 62, n. 4, p. 980-984, 2010.

DIAS, D. L. S.; SILVA, R. R.; SILVA, F. F.; CARVALHO, G. G. P.; BARROSO, D. S.; CARVALHO, V. M. Correlation between performance and ingestive behavior of steers post-weaned on pastures. Acta Scientiarum Animal Sciences, Maringá, v. 36, n. 1, p. 85-91, 2014.

LICITRA, G.; HERNANDEZ, T. M.; VAN SOEST, P. J. Standartization of procedures for nitrogen fractionation of ruminants feeds. Animal Feed Science and Technology, Amsterdam, v. 57, n. 4, p. 347-358, 1996.

MCLEOD, M. N.; MINSON, D. J. Breakdown of large particles in forage by simulated digestion and detrition. Journal of animal science, Champaign, v. 66, n. 4, p. 1000-1004, 1988. 
MERTENS, D.R. Gravimetric determination of amylasetreated neutral detergent fiber in feeds with refluxing in beakers or crucibles: collaborative study. Journal of $A O A C$ international, Gaithersburg, v. 85, n. 6, p. 12171240, 2002.

NATIONAL RESEARCH COUNCIL - NRC. Nutrient requirements of small ruminants. Washington: National Academy. 2007. 362 p.

PERAZZO, A. F.; HOMEM NETO, S. P.; RIBEIRO, O. L.; SANTOS, E. M.; CARVALHO, G. G. P.; OLIVEIRA, J. S.; BEZERRA, H. F. C.; CAMPOS, F. S.; FREITAS JUNIOR, J. E. Intake and ingestivo behavior of lambs fed diets containing ammoniated buffel grass hay. Tropical Animal Health and Production, Edinburgh, v. 49, n. 4, p. 717-724, 2017.

PERAZZO, A. F.; HOMEM NETO, S. D. P.; RIBEIRO, O. L.; SANTOS, E. M.; CARVALHO, G. G. P.; OLIVEIRA, J. D. S.; RODRIGUES, T. C. G. C.; PINHO, R. M. A. Correlations of intake, digestibility and performance with the ingestive behavior of lambs fed diets containing ammoniated buffel grass hay. Semina: Ciências Agrarias, Londrina, v. 37, n. 3, p. 1551-1563, 2016.

SCHNEIDER, B. H.; FLATT, W. P. The evaluation of feeds through digestibility experiments. Athens: University Georgia, 1975. 423 p.
UNIVERSIDADE FEDERAL DE VIÇOSA - UFV. Sistema para análises estatísticas - SAEG. Versão 9.1. Viçosa, MG: Fundação Arthur Bernardes, UFV, 2007.

SILVA, A. L. N.; SILVA, R. R.; CARVALHO, G. G. P.; LINS, T. O. J. A.; ZEOULA, L. M.; FRANCO, S. L.; SOUZA, S. O.; PEREIRA, M. M. S.; BARROSO, D. S. Correlation between ingestive behaviour, intake and performance of grazing cattle supplemented with or without propolis extract (LLOS). Journal of Agricultural and Crop Research, v. 2, n. 1, p. 1-10, 2014.

SILVA, D. J.; QUEIROZ, A. C. Análise de alimentos: métodos químicos e biológicos. 3. ed. Viçosa, MG: Editora UFV - Universidade Federal de Viçosa, 2002. $235 \mathrm{p}$.

WEISS, W. P. Energy prediction equations for ruminant feeds. In: Cornell nutrition conference for feed manufacturers. Ithaca: Cornell University, 1999. p. 176185.

WELCH, J. G. Rumination, particle size and passage from the rumen. Journal of Animal Science, Champaign, v. 54, n. 4 , p. 176-185, 1982. 